\title{
Nutrient fluxes in litterfall of a secondary successional alluvial rain forest in Southern Brazil
}

\author{
Maurício Bergamini Scheer ${ }^{1,2}$, Gustavo Gatti ${ }^{3} \&$ Celina Wisniewski ${ }^{2}$ \\ 1. Sanepar/DMA, Assessoria de Pesquisa e Desenvolvimento, Rua Engenheiros Rebouças, 1376, Rebouças, 80215-900, \\ Curitiba, Paraná, Brazil; mauriciobs@sanepar.com.br \\ 2. Universidade Federal do Paraná, Programa de Pós-Graduação em Engenharia Florestal, Av. Pref. Lothário Meissner, \\ 900, Jardim Botânico - Campus III, 80210-170, Curitiba, Paraná, Brazil; cewisni@ufpr.br \\ 3. Fundação Grupo Boticário de Proteção à Natureza, Rua Gonçalves Dias, 225, Batel, 80240-340, Curitiba, PR, Brazil; \\ gustavo@fundacaoboticario.org.br
}

\author{
Received 06-XII-2010. C Corrected 30-III-2011. Accepted 27-IV-2011.
}

\begin{abstract}
During forest succession, litterfall nutrient fluxes increase significantly. The higher inputs of organic matter and nutrients through litterfall affects positively soil fertility and the species composition, which are essential components in forest restoration and management programs. In the present study, the input of nutrients to the forest soil via litterfall components was estimated for two sites of different development stages, in an early successional alluvial rain forest in Brazil. Litterfall returned to the soil, in $\mathrm{kg} / \mathrm{ha}$, ca. $93 \mathrm{~N}, 79 \mathrm{Ca}, 24 \mathrm{~K}$, $15 \mathrm{Mg}, 6 \mathrm{P}, 1.7 \mathrm{Mn}, 0.94 \mathrm{Fe}, 0.18 \mathrm{Zn}, 0.09 \mathrm{Cu}$ and $11.2 \mathrm{Al}$, in the site where trees were more abundant and had higher values of basal area. In the other area, where trees where less abundant and values of basal area were comparatively low, litterfall returned $<50 \%$ of those amounts to the forest soil, except for Al. The amount of Al that returned to the soil was similar in both areas due to the high contribution of Tibouchina pulchra (82\% of Al returned). Comparatively, high proportion of three dominant native tree species (Myrsine coriacea, T. pulchra and Cecropia pachystachya) explained better litter nutrient use efficiency (mainly $\mathrm{N}$ and $\mathrm{P}$ ) in the site with the least advanced successional stage. Although litterfall of these species show lower nutrient concentrations than the other tree species, their nutrient fluxes were high in both sites, indicating a certain independence from soil essential nutrients. Such feature of the native species is very advantageous and should be considered in forest restoration programs. Rev. Biol. Trop. 59 (4): 1869-1882. Epub 2011 December 01.
\end{abstract}

Key words: litter production, nutrient cycling, nutrient use efficiency, secondary succession, tropical rain forest.

The conversion of natural forests into agricultural and pasture areas disturbs natural nutrient cycling and soil organic matter content, resulting in loss of nutrients from the ecosystem. This phenomenon has been observed over the last few decades in large portions of the alluvial plains of the Brazilian Atlantic coast. Even though the Brazilian Forest Code (1965) and the National System of Conservation Units-SNUC (2000) now protect most of these areas, forests were severely damaged in the past, and most of the present vegetation is at an early to an intermediate stage of secondary succession. A successful management of these areas, in order to achieve a fast natural recovery, requires a better understanding of secondary successional processes and related nutrient cycling.

The forest floor acts as an input-output system. Plant litter contributes significantly to soil organic matter and to mineralization through decomposition processes, maintaining site fertility and productivity (Prescott 2005). The reestablishment of this system is highly important during succession, particularly in tropical forests, where most available nutrients are generally bound to vegetation biomass or to the organic matter of the upper soil layers 
(Brown \& Lugo 1982, Ranger et al. 2003). The regeneration capacity of these ecosystems depends mainly on the soil degradation level.

Litterfall is an important indicator of primary productivity, nutrient fluxes and carbon transfer in forest ecosystems (Bray \& Gorham 1964, Ranger et al. 2003). Nutrient-cycling pathways and nutrient-use efficiency are critical factors to consider the suitability of tree species to the different conditions present in forest stands undergoing restoration (Vitousek 1982, Lugo et al. 2004). The ratio between litterfall mass and litterfall nutrient content, or the inverse of nutrient concentrations in litterfall (Nutrient Use Efficiency-NUE, according to Vitousek 1982, 1984) can be used as an index of nutrient-use efficiency. Even though studies involving soil fertility or nutrient availability and other components of nutrient-use efficiency (Vitousek 1997), as well as potential and realized resorption (Killingbeck 1996) are available, the litterfall mass:literfall nutrient content ratio is commonly used to compare ecosystems, sites and species (Silver 1994). This approach works best when the litterfall mass is a fixed proportion of ecosystem production (Vitousek 1982, Binkley et al. 2004).

Data on mineral cycling and secondary succession of alluvial plains in Brazilian Atlantic rain forests are scarce. Therefore, as part of a medium-term ecological study in an alluvial Atlantic rain forest, continuing the study by Scheer et al. (2009), this paper reports: (1) the role of common tree species in organic matter, nutrient (N, P, K, Ca, Mg, Fe, Mn, Cu, Zn) and $\mathrm{Al}$ mineralization through litterfall in a nine to ten year-old regenerating forest divided in two sites differing in tree abundance and values of basal area; (2) the differences in nutrient-use efficiency among species and between sites and its associated implications for succession; and (3) comparisons of observed nutrient fluxes to those of other tropical and subtropical forests.

\section{MATERIAL AND METHODS}

Study area: The regenerating alluvial Atlantic rain forest (Floresta Ombrófila Densa, according to the Brazilian official classification, Veloso et al. 1991) is located at Salto Morato Natural Reserve (RNSM) at an altitude of 20m.a.s.l., in Guaraqueçaba, Northeastern coast of Paraná state, Brazil (25 $5^{\circ} 10^{\prime} 45^{\prime \prime} \mathrm{S}$ $\left.48^{\circ} 17^{\prime} 48^{\prime \prime} \mathrm{W}\right)$ (detailed location in Scheer et al. 2009). The vegetation of this area is typical of the alluvial plains along the Brazilian coastline. Soils within the study area are originally Cenozoic sediments from Serra do Morato (uplifted blocks of igneous and high-grade metamorphic rocks) and are predominantly medium-textured Fluvisols and Cambisols (World Reference Base for Soil Resources-FAO-WRB 1998) (Scheer et al. 2009). In the past, the area was used for water-buffalo grazing, but at about nine to ten years before this study, this activity was ceased, allowing vegetation to regenerate. The area (about 7ha), was stratified into two sites according to differences in tree abundance and values of basal areas in order to reduce sampling errors (Table 1). These variables were estimated in ten plots of $100 \mathrm{~m}^{2}$ (perimeter at breast height $\geq 10 \mathrm{~cm}$ ), each of them covering the whole area, which was randomly selected in a previous study (Gatti 2000).

Site 1: Most advanced vegetation (Table 1). Located at about $100 \mathrm{~m}$ from an advanced secondary successional stage of a lower montane rain forest, a major propagule source. At the time this study was performed, the canopy was dominated by Myrsine coriacea (Sw.) R. Br. ex Roem. and Schult., Myrsinaceae; Senna multijuga (Rich.) H. S. Irwin and Barneby, Fabaceae; Cecropia pachystachya Trécul, Urticaceae; and Tibouchina pulchra Cogn., Melastomataceae. Citharexylum myrianthum Cham. (Verbenaceae), a species from a previous secondary forest, was scattered throughout the site. Piper aduncum L. and Boehmeria caudata $\mathrm{Sw}$. are frequent species among shrubs. In the herbaceous stratum, Cyrtocymura scorpioides (Lam.) H. Rob. and Manettia congesta (Vell.) K. Schum. were widespread. Hieronyma alchorneoides Allemão and Vochysia bifalcata Warm seedlings, species that would probably 
TABLE 1

Stand characteristics and soil properties of the study sites

\begin{tabular}{|c|c|c|c|}
\hline & Parameters* & $\begin{array}{c}\text { Site } 1 \\
\text { (most advanced) }\end{array}$ & $\begin{array}{c}\text { Site } 2 \\
\text { (least advanced) }\end{array}$ \\
\hline \multirow{13}{*}{ 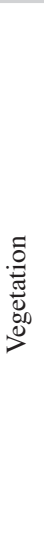 } & Age (years) & $9-10$ & $9-10$ \\
\hline & Mean tree height (m) & 8 & 6 \\
\hline & Number of tree species & 36 & 24 \\
\hline & Stand density (trees $/ \mathrm{ha}, \mathrm{PBH} \geq 10 \mathrm{~cm}$ ) & 2820 & 1130 \\
\hline & Basal area $\left(\mathrm{m}^{2} / \mathrm{ha}\right)$ & 22.2 & 6.7 \\
\hline & Dominant early successional tree specie & & \\
\hline & Myrsine coriacea & 14 & 22 \\
\hline & Cecropia pachystachya & 11 & 22 \\
\hline & Tibouchina pulchra & 5 & 20 \\
\hline & Senna multijuga & 10 & 9 \\
\hline & Psidium guajava & 4 & 7 \\
\hline & Alchornea glandulosa & 2 & 1 \\
\hline & Citharexylum myrianthum & 28 & 4 \\
\hline \multirow{14}{*}{ 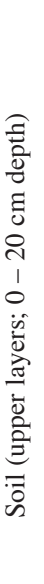 } & Other species & 26 & 15 \\
\hline & Soils* & \multicolumn{2}{|c|}{ Medium textured Fluvisols and Cambisols } \\
\hline & $\mathrm{pH}\left(\mathrm{CaCl}_{2}\right)$ & 4.2 & 4.1 \\
\hline & $\mathrm{P}(\mathrm{mg} / \mathrm{kg})$ & 0.4 & 0.4 \\
\hline & $\mathrm{Na}^{+}\left(\mathrm{cmol}_{\mathrm{c} /} \mathrm{kg}\right)$ & 0.07 & 0,06 \\
\hline & $\mathrm{K}^{+}\left(\mathrm{cmol}_{\mathrm{c}} \mathrm{kg}\right)$ & 0.12 & 0.09 \\
\hline & $\mathrm{Ca}^{2+}\left(\mathrm{cmol}_{\mathrm{c}} \mathrm{kg}\right)$ & 1.33 & 1.38 \\
\hline & $\mathrm{Mg}^{2+}\left(\mathrm{cmol}_{\mathrm{c} /} \mathrm{kg}\right)$ & 0.86 & 0.94 \\
\hline & $\mathrm{Al}^{3+}\left(\mathrm{cmol}_{\mathrm{c}} \mathrm{kg}\right)$ & 1.92 & 1.91 \\
\hline & $\mathrm{H}+\mathrm{Al}^{3+}\left(\mathrm{cmol}_{\mathrm{c} /} \mathrm{kg}\right)$ & 8.27 & 9.93 \\
\hline & $\mathrm{S}\left(\mathrm{cmol}_{\mathrm{c} / \mathrm{kg}}\right)$ & 2.4 & 2.5 \\
\hline & $\mathrm{CEC}\left(\mathrm{cmol}_{\mathrm{c} /} \mathrm{kg}\right)$ & 10.7 & 12.4 \\
\hline & BS $\%$ & 22.6 & 20.2 \\
\hline & $\mathrm{OM}(\mathrm{g} / \mathrm{kg})$ & 49.4 & 45.1 \\
\hline
\end{tabular}

$\mathrm{S}=$ sum of bases $\left(\mathrm{Na}^{+}+\mathrm{Ca}^{2+}+\mathrm{Mg}^{2+}+\mathrm{K}^{+}\right), \mathrm{CEC}=$ cation-exchange capacity $\left(\mathrm{S}+\left(\mathrm{H}+\mathrm{Al}^{3+}\right)\right), \mathrm{BS}=$ base saturation $(100 * \mathrm{~S} / \mathrm{CEC})$, $\mathrm{OM}=$ organic matter.

* Vegetation and Soil data $(\mathrm{n}=10)$ from Gatti (2000) and Scheer (2006).

dominate the community in the next successional stage were also observed.

Site 2: Least advanced vegetation (Table 1). This site holds partially the same species as site 1 . However, the trees were more sparsely distributed, rarely forming a continuous canopy. Shrubs such as Vernonanthura beyrichii (Less.) H. Rob. and Solanum fastigiatum Willd. were frequent. Cyrtocymura scorpioides, Paspalum wettsteinii Hack. and
Brachiaria mutica (Forsk.) Stapf. dominate the herbaceous community.

Even though both sites (same age) were at a similar successional stage before early grazing activities and were growing on soils with similar chemical conditions (Table 1), some possible reasons to explain present differences in tree abundance and values of basal area are: (1) site 2 is farther from the secondary forest than site 1 (about $100 \mathrm{~m}$ ) and is about $50 \mathrm{~m}$ closer to a rural road, indicating lower possibility 
of receiving propagules from the secondary forest; (2) before forest regeneration, the water buffalo grazing was more intense in site 2 than in site 1, and invasion of Brachiaria spp. (alien invasive species) from neighboring areas with hydromorphic Histosols might have happened, delaying the successional process.

Climate: The daily mean temperature during the coldest month is $18^{\circ} \mathrm{C}$ and the mean temperature during the warmest month is about $22^{\circ} \mathrm{C}$, with hot and wet summers (January-March) and a less pronounced dry season. The mean annual rainfall is $2403 \mathrm{~mm}$ (Scheer 2008). During the period of this study, annual average rainfall in the study area was $2676 \mathrm{~mm}$, with no differences between years $(\mathrm{p}<0.01)$. The highest rainfall rates occurred in February 2002 (about $572 \mathrm{~mm}$ ) and the lowest ones in June 2002 (47mm) (Scheer 2009, Scheer et al. 2009). The climate of this region is considered subtropical or transitional tropical (Maack 1968).

Litterfall collection and partition: For each site, thirty $0.5 \mathrm{~m}^{2}$ circular fixed litter traps were placed in $10\left(100 \mathrm{~m}^{2}\right)$ plots (three traps per plot). Litterfall was collected fortnightly from September 2001 to September 2003. On a monthly basis (28 days) the material (total fine above-ground litterfall) from three traps of each plot was then pooled together to form one sample ( $n=10$ per site). After air-drying, each sample was divided into four fractions: leaves; reproductive parts; twigs $\leq 2 \mathrm{~cm}$ in diameter; and miscellaneous material composed by small leaf, bark, twig and insect fragments. Leaves were then split into eight subfractions, summing up 11 subfractions. Seven of the leaf subfractions were composed of the most abundant tree species (M. coriacea; S. multijuga; C. pachystachya; T. pulchra; Alchornea glandulosa Poepp. And Endl., Euphorbiaceae; C. myrianthum and Psidium guajava L., Myrtaceae) and one was composed of leaves from all other tree species in the community. Each fraction was dried at $65^{\circ} \mathrm{C}$ to a constant weight, and then ground and homogenized. The seven studied species of site 1 comprised about $60 \%$ of the total tree abundance and $90 \%$ of the total value of basal area. The corresponding values for site 2 were $74 \%$ and $85 \%$ (Table 1).

Chemical analyses: Every third month, the 11 subfractions were pooled together by category in order to form a seasonal sample for each year (two years=eight sampling periods). The seasonal sample was then divided into two subsamples for analysis as follows:

Nutrient content of total litterfall: The first subsample of each seasonal sample was grouped to determine the nutrient concentration of total litterfall per plot in each site $(\mathrm{n}=10$ per site $)$.

Nutrient content of litterfall components: Even though nutrient concentrations of leaf litter mass often varied between sites for a given species, the second subsample of each fraction from site 1 was combined with the corresponding material from site 2 . This resulted in 11 combined samples of litter components for each of the eight sampling periods (eight replications per each litter component).

In the present study, the total aboveground fine litterfall fluxes were calculated as the sum of the litterfall components (using the concentrations of each fraction).

Chemical analyses were carried out at the Biogeochemistry Laboratory of the Federal University of Paraná, Brazil. The N (Kjeldahl method), $\mathrm{K}, \mathrm{Ca}, \mathrm{Mg}, \mathrm{Fe}, \mathrm{Mn}, \mathrm{Cu}, \mathrm{Zn}$ and $\mathrm{Al}$ analyses were performed according to Martins \& Reissmann (2007), using a Perkin-Elmer 2380 atomic absorption spectrophotometer. Potassium was determined by emission and $\mathrm{P}$ was analyzed by colorimetry with a UV/VIS 554 Perkin-Elmer spectrophotometer (ammonium vanadate-molybdate method).

Carbon concentrations of total leaf litter (using a Leco CN-2000 dry combustion analyzer) and of the remaining dry mass after one year of decomposition (experiment carried out during the same period of this study, data from Scheer 2008) were used to estimate the 
amount of this element on the forest floor. The nutrient content of litterfall was determined as the product between nutrient concentration and litterfall mass.

Standard errors were calculated for each mineral element concentration. Data were ln-transformed whenever necessary to satisfy assumptions of normality and equality of variance. A paired t-test was performed to test whether there were differences in annual mean concentrations in total litterfall between sites, and a repeated-measure ANOVA (rm-ANOVA) was performed to test differences of mineral element concentration among fractions. "Season" was assigned as the within-subject factor and "fractions" was assigned as the betweensubject factor. Because the data did not satisfy the assumption of sphericity (Mauchly's test), the degrees of freedom were corrected using Greenhouse-Geisser estimates of sphericity. Differences in between-subject factors were further evaluated using Duncan test. Data were explored using the software SSPS 13.0 (Statistical Package for Social Sciences) for Windows.

\section{RESULTS}

Amount of litterfall: The total annual amount of litterfall in site 1 was $6.4 \pm 1.2 \mathrm{mg} / \mathrm{ha}$ (95\% confidence interval) and only $3.0 \pm 1.0 \mathrm{mg} /$ ha in site 2 . The highest amount of litterfall was observed at the beginning of the rainy season, which occurred three months before the annual peaks of rainfall and temperatures (Scheer $e t$ al. 2009).

In the plots of site 1, leaf litter comprised $69 \%$ of total litterfall whereas in site 2 leaf litter contribution was ca. $80 \%$. Total litterfall in site 2 showed a higher $(56 \%)$ relative contribution of the three dominant species listed in Table 1 than in site $1(22 \%)$.

Based on data published by Scheer (2008), the carbon concentration in total leaf litterfall was $440 \mathrm{~g} / \mathrm{kg}$ in samples collected from the same area. After one year of decomposition, the carbon concentration in the remaining dry mass (about 50\%) was 340g/kg (Scheer 2008). Therefore, the annual amount of carbon from litterfall origin on the forest floor was $2.81 \mathrm{Mg} /$ ha in site 1 . After one year decomposing, only $1090 \mathrm{kgC} /$ ha remained as litter standing crop. The corresponding values for site 2 were 1 $320 \mathrm{kgC} / \mathrm{ha} / \mathrm{yr}$ and $510 \mathrm{kgC} / \mathrm{ha}$, respectively.

Mineral elements in litterfall: Average concentrations of $\mathrm{N}, \mathrm{P}, \mathrm{K}, \mathrm{Ca}, \mathrm{Mg}, \mathrm{Cu}$ and $\mathrm{Zn}$ in total litterfall of site 1 (higher basal area and tree abundance) were significantly higher than that of site 2, while Al concentrations of site 2 were higher (Table 2). $\mathrm{N}$ and $\mathrm{Ca}$ had the highest concentrations of all the elements in almost all the litter components, followed by $\mathrm{K}, \mathrm{Mg}$,

TABLE 2

Annual average concentration of nutrients and aluminum in total litterfall of two sites in a secondary alluvial Atlantic rain forest (mean \pm SE; $n=8)$

\begin{tabular}{|c|c|c|c|c|c|c|c|c|}
\hline \multirow[b]{2}{*}{$\mathrm{N}$} & & \multicolumn{3}{|c|}{ Site 1} & \multicolumn{3}{|c|}{ Site 2} & \multirow{2}{*}{$\begin{array}{c}p \text { value (paired } t \text {-test) } \\
<0.05\end{array}$} \\
\hline & \multirow{5}{*}{ क्षि } & 14.45 & \pm & 1.09 & 11.58 & \pm & 0.39 & \\
\hline $\mathrm{P}$ & & 0.96 & \pm & 0.04 & 0.78 & \pm & 0.07 & $<0.05$ \\
\hline $\mathrm{K}$ & & 4.38 & \pm & 0.15 & 3.85 & \pm & 0.23 & $<0.05$ \\
\hline $\mathrm{Ca}$ & & 14.87 & \pm & 0.24 & 13.68 & \pm & 0.37 & $<0.01$ \\
\hline $\mathrm{Mg}$ & & 2.64 & \pm & 0.22 & 2.35 & \pm & 0.17 & $<0.01$ \\
\hline $\mathrm{Fe}$ & \multirow{5}{*}{$\begin{array}{l}\stackrel{\partial 00}{b} \\
\stackrel{y}{b 0} \\
\Xi \\
\Xi\end{array}$} & 141.8 & \pm & 7.1 & 138.0 & \pm & 8.0 & $=0.61$ \\
\hline $\mathrm{Mn}$ & & 275.9 & \pm & 13.9 & 246.4 & \pm & 13.7 & $=0.09$ \\
\hline $\mathrm{Cu}$ & & 12.4 & \pm & 0.3 & 11.2 & \pm & 1.2 & $<0.01$ \\
\hline $\mathrm{Zn}$ & & 25.9 & \pm & 0.9 & 18.3 & \pm & 0.5 & $<0.01$ \\
\hline $\mathrm{Al}$ & & 1910.9 & \pm & 164.1 & 3070.6 & \pm & 243.3 & $<0.01$ \\
\hline
\end{tabular}


and $\mathrm{P}$ (Table 3). The gradient in micronutrient concentration was as follow: $\mathrm{Mn}>\mathrm{Fe}>\mathrm{Zn}>\mathrm{Cu}$ (Table 3).

The total annual amounts of mineral elements returned to the forest floor from site 1 were (in $\mathrm{kg} / \mathrm{ha}$ ): $93 \mathrm{~N}, 79 \mathrm{Ca}, 24 \mathrm{~K}, 15 \mathrm{Mg}, 6 \mathrm{P}$, 1.7 Mn, 0.94 Fe, 0.18 Zn, 0.09 Cu and 11.2 Al. Except for Al, less than half of these amounts were added to the forest floor in site 2, (Table 4). Leaf litter contributed with $75 \%$ of macronutrients, $67 \%$ of micronutrients and $81 \%$ of $\mathrm{Al}$ in site 1 ; for site 2 , these values were $81 \%, 75 \%$ and $93 \%$, respectively (Table 4). The input of macronutrients and micronutrients via litterfall of the three main tree species was respectively ca. $27 \%$ and $21 \%$ in site 1 and $54 \%$ and $45 \%$ in site 2 .

Specific results for nutrient concentrations and fluxes via litterfall components (Table 3 and 4) as well as comparisons with other forests (Table 5) are discussed below.

\section{DISCUSSION}

Nutrient concentrations in total litterfall: The concentrations of most of the studied elements were significantly higher in total litterfall of site 1 than in site 2 . This can be explained by the fact that total litterfall of site 2 was dominated by the three species with comparatively large basal areas and low levels of nutrients. Lower nutrient availability in soil can lead to high nutrient-use efficiencies (Vitousek 1982, Gallardo et al. 1999, Dent et al. 2006). A decrease in the efficiency of nutrient use (considered as the inverse of nutrient concentrations in litterfall) can occur along the process of forest regeneration, improving soil fertility for late successional species (Vitousek 1982). In fact, it has been reported for more advanced stages of succession or across gradients of forest productivity, that biomass increments become driven by woody biomass, diluting the proportion of leaves in litterfall (Bray \& Gorham 1964, Rodin \& Basilevich 1967, Vitousek \& Reiners 1975, Binkley et al. 2004). Therefore, we should not expect the $\mathrm{N}$ use efficiency to decline as $\mathrm{N}$ supply increases (Binkley et al. 2004). In the second year studied (from the $9^{\text {th }}$ to the $10^{\text {th }}$ year of forest regeneration), the least advanced vegetation (site 2 ) had a higher increase in biomass and nutrient rates than that of the most advanced vegetation (site 1) (Gatti et al. unpublished data).

Aluminum concentrations in site 2 were significantly higher than in site 1 due to the higher contribution of T. pulchra $(\mathrm{p}<0.01)$, an $\mathrm{Al}$-accumulating species. No clear evidence of seasonality for nutrient or Al concentrations was found (data not presented), a pattern also observed for other Brazilian Atlantic rain forests (Domingos et al. 1997). However, some studies (Sampaio et al.1988, Domingos et al. 1990) observed higher $\mathrm{K}, \mathrm{Mg}, \mathrm{Na}, \mathrm{Mn}$, and B concentrations in dryer months, which can be partially related to a lower degree of leaching from litter traps.

Macronutrient concentrations in components of litterfall: There was neither a significant difference between mineral element concentrations among seasons nor an interaction between the factors "Season" and "Fractions" (rm-ANOVA, p>0.05). Concentrations of $\mathrm{N}$ and $\mathrm{P}$ within miscellaneous materials were significantly higher than in leaf litter of selected species, probably due to the decomposition of animal material (e.g. excrement and arthropod fragments), as well as leaf fragments (Domingos et al. 1997). Among leaf litter fractions, significantly higher $\mathrm{N}$ concentrations were observed in A. glandulosa and S. multijuga. These species probably exhibit a more efficient $\mathrm{N}$ uptake from soil or a greater demand for this element. This could indicate that these species do not have a high nutrient use efficiency (NUE), or during the studied years they presented low resorption, as suggested by Killinbeck (1996). The average $\mathrm{N}$ concentrations were at intermediate ranges comparing to data from the literature (10 to $20 \mathrm{~g} / \mathrm{kg}$ dry weight or 100 to 20 NUE respectively). This range was observed in Amazonian and slope Atlantic rain forests. Higher $\mathrm{N}$ concentrations (between 20 and $35 \mathrm{~g} /$ $\mathrm{kg}$ ) were observed in Brazilian deciduous and semideciduous forests that generally occur on 


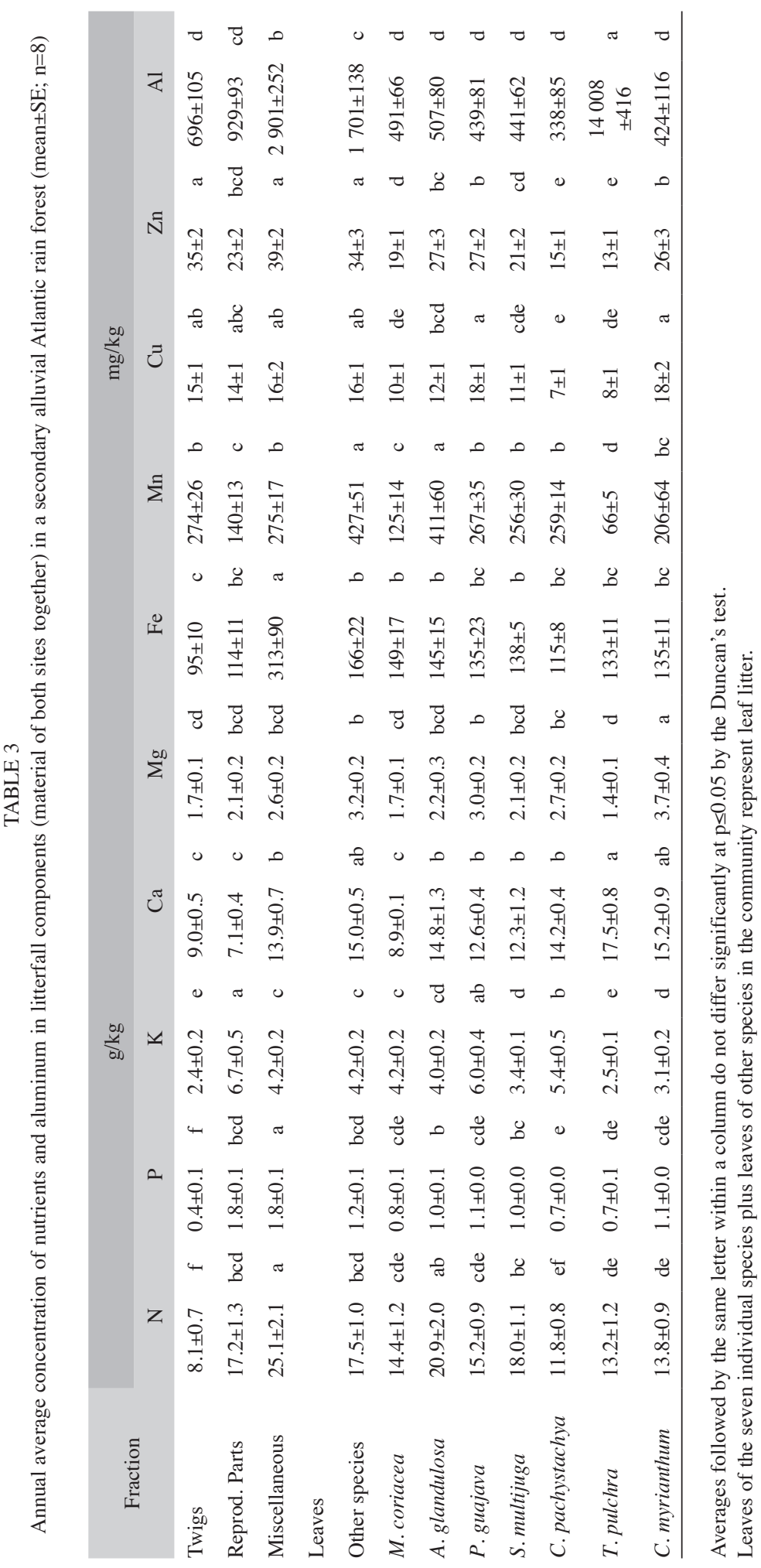


TABLE 4

Annual average of litterfall $(\mathrm{n}=10)$, nutrients and aluminum $(\mathrm{kg} / \mathrm{ha} / \mathrm{yr})$ content in litterfall components at two sites in a secondary alluvial Atlantic rain forest

\begin{tabular}{|c|c|c|c|c|c|c|c|c|c|c|c|c|}
\hline & Fraction & Litterfall & $\mathrm{N}$ & $\mathrm{P}$ & K & $\mathrm{Ca}$ & $\mathrm{Mg}$ & $\mathrm{Fe}$ & $\mathrm{Mn}$ & $\mathrm{Cu}$ & $\mathrm{Zn}$ & $\mathrm{Al}$ \\
\hline \multirow{10}{*}{ 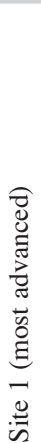 } & Twigs & 1396 & 10.47 & 0.46 & 3.12 & 11.98 & 2.12 & 0.129 & 0.369 & 0.021 & 0.050 & 0.855 \\
\hline & Reproductive parts & 285 & 4.96 & 0.49 & 1.85 & 1.98 & 0.61 & 0.034 & 0.040 & 0.004 & 0.006 & 0.255 \\
\hline & Miscellaneous & 326 & 7.90 & 0.56 & 1.33 & 4.39 & 0.84 & 0.109 & 0.086 & 0.005 & 0.013 & 0.998 \\
\hline & \multicolumn{12}{|l|}{ Leaves } \\
\hline & Other species including* & 1965 & 24.20 & 1.53 & 5.87 & 20.24 & 3.75 & 0.255 & 0.590 & 0.021 & 0.047 & 2.674 \\
\hline & Myrsine coriacea & 658 & 9.49 & 0.51 & 2.71 & 5.83 & 1.09 & 0.101 & 0.085 & 0.007 & 0.013 & 0.300 \\
\hline & Alchornea glandulosa & 244 & 5.62 & 0.25 & 0.94 & 3.99 & 0.55 & 0.035 & 0.114 & 0.003 & 0.007 & 0.113 \\
\hline & Psidium guajava & 318 & 4.92 & 0.34 & 1.86 & 4.12 & 1.00 & 0.049 & 0.101 & 0.006 & 0.009 & 0.139 \\
\hline & Senna multijuga & 408 & 7.23 & 0.38 & 1.37 & 4.77 & 0.83 & 0.057 & 0.099 & 0.004 & 0.008 & 0.170 \\
\hline & Cecropia pachystachya & 391 & 4.76 & 0.28 & 2.00 & 5.51 & 1.02 & 0.045 & 0.102 & 0.003 & 0.006 & 0.131 \\
\hline & Tibouchina pulchra & 376 & 5.10 & 0.27 & 0.94 & 6.55 & 0.53 & 0.051 & 0.025 & 0.003 & 0.005 & 5.308 \\
\hline & Total of the 6 species & 2395 & 37.12 & 2.03 & 9.82 & 30.77 & 5.02 & 0.338 & 0.526 & 0.026 & 0.048 & 6.154 \\
\hline & Citharexylum myrianthum* & $(616)$ & 8.05 & 0.65 & 2.02 & 9.80 & 2.48 & 0.080 & 0.102 & 0.012 & 0.018 & 0.219 \\
\hline & Total leaf litterfall & 4360 & 61.32 & 3.56 & 15.69 & 51.01 & 8.77 & 0.59 & 1.12 & 0.05 & 0.10 & 8.82 \\
\hline & TOTAL $* *$ & 6367 & 92.72 & 5.71 & 24.02 & 79.19 & 14.83 & 0.944 & 1.713 & 0.089 & 0.183 & 11.163 \\
\hline & Twigs & 335 & 2.63 & 0.11 & 0.75 & 2.86 & 0.53 & 0.030 & 0.093 & 0.005 & 0.012 & 0.233 \\
\hline & Reproductive parts & 184 & 3.42 & 0.34 & 1.23 & 1.30 & 0.42 & 0.020 & 0.027 & 0.003 & 0.004 & 0.157 \\
\hline & Miscellaneous & 93 & 2.19 & 0.16 & 0.38 & 1.25 & 0.25 & 0.032 & 0.025 & 0.001 & 0.004 & 0.277 \\
\hline \multicolumn{13}{|c|}{ Leaves } \\
\hline छิ & Other species including* & 455 & 4.60 & 0.29 & 1.14 & 3.79 & 0.64 & 0.05 & 0.12 & 0.00 & 0.01 & 0.540 \\
\hline 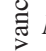 & Myrsine coriacea & 288 & 4.19 & 0.22 & 1.18 & 2.54 & 0.48 & 0.044 & 0.037 & 0.003 & 0.006 & 0.130 \\
\hline 胥 & Alchornea glandulosa & 10 & 0.21 & 0.01 & 0.03 & 0.15 & 0.02 & 0.001 & 0.005 & 0.000 & 0.000 & 0.004 \\
\hline$\stackrel{\vec{g}}{\stackrel{\vec{g}}{\Xi}} I$ & Psidium guajava & 76 & 1.19 & 0.08 & 0.44 & 0.99 & 0.25 & 0.012 & 0.027 & 0.001 & 0.002 & 0.032 \\
\hline N & Senna multijuga & 159 & 2.78 & 0.15 & 0.53 & 1.94 & 0.34 & 0.022 & 0.041 & 0.002 & 0.003 & 0.072 \\
\hline$\stackrel{\mathscr{C}}{n}$ & Cecropia pachystachya & 844 & 10.26 & 0.61 & 4.55 & 12.04 & 2.24 & 0.100 & 0.221 & 0.006 & 0.014 & 0.241 \\
\hline & Tibouchina pulchra & 567 & 7.83 & 0.41 & 1.41 & 9.76 & 0.79 & 0.077 & 0.037 & 0.005 & 0.007 & 7.923 \\
\hline & Total of the 6 species & 1944 & 26.46 & 1.48 & 8.14 & 27.42 & 4.12 & 0.26 & 0.37 & 0.02 & 0.03 & 8.379 \\
\hline & Citharexylum myrianthum* & $(204)$ & 2.69 & 0.21 & 0.66 & 3.26 & 0.82 & 0.027 & 0.036 & 0.004 & 0.006 & 0.076 \\
\hline & Total leaf litterfall & 2399 & 31.06 & 1.77 & 9.28 & 31.21 & 4.76 & 0.30 & 0.49 & 0.02 & 0.04 & 8.92 \\
\hline & TOTAL** & 3011 & 41.99 & 2.60 & 12.30 & 39.87 & 6.78 & 0.412 & 0.670 & 0.035 & 0.067 & 9.688 \\
\hline
\end{tabular}

* Leaf litter of Citharexylum myrianthum were sampled separately only in the second year.

** Fluxes calculated as the sum of the litterfall components (using the concentrations of each fraction).

Leaves of the seven individual species plus leaves of other species represent total leaf litter. 
TABLE 5

Total litterfall and nutrient fluxes in some tropical and subtropical forests

\begin{tabular}{|c|c|c|c|c|c|c|c|c|c|c|c|c|c|}
\hline & tune/cite & Soil Information & & & & & & th & a/yr & & & & \\
\hline & pe/site & (FA Q WDP) & $\mathrm{kg} / \mathrm{ha} / \mathrm{yr}$ & $\mathrm{N}$ & $\mathrm{P}$ & $\mathrm{K}$ & $\mathrm{Ca}$ & $\mathrm{Mg}$ & $\mathrm{Fe}$ & $\mathrm{Mn}$ & $\mathrm{Cu}$ & $\mathrm{Zn}$ & $\mathrm{Al}$ \\
\hline ATLANTIC DEN & RAIN FORESTS & & & & & & & & & & & & \\
\hline Restinga $^{1}$ & & Podzols & 3900 & 28 & 1 & 7 & 30 & 11 & 0.5 & 1.5 & 0.0 & 0.1 & 1.3 \\
\hline Restinga $^{2}$ & Between beach ridge & Podzols & 7673 & 82 & 2 & 28 & 51 & 1 & 0.8 & 1.1 & 0.1 & 0.1 & 3.9 \\
\hline Restinga $^{2}$ & On beach ridge & Podzols & 5235 & 39 & 1 & 17 & 35 & 13 & 0.4 & 1.1 & 0.0 & 0.1 & 1.6 \\
\hline Restinga $^{3}$ & On beach ridge & Podzols & 5080 & 57 & 4 & 12 & 65 & 16 & 0.9 & 0.8 & 0.0 & 0.2 & - \\
\hline Alluvial & SITE 1 - This study & Fluvisols & 6367 & 93 & 6 & 24 & 79 & 15 & 0.9 & 1.7 & 0.09 & 0.18 & 11.2 \\
\hline Alluvial & SITE 2 - This study & Fluvisols & 3011 & 42 & 3 & 12 & 40 & 7 & 0.4 & 0.7 & 0.04 & 0.07 & 9.7 \\
\hline Lower Montane ${ }^{1}$ & - & - & 6300 & 102 & 4 & 20 & 60 & 19 & 1.2 & 4.6 & 0.1 & 0.2 & 5.3 \\
\hline Lower Montane ${ }^{4}$ & Affected by pollution & Ferral./Cambi. & 1803 & 46 & 2 & 6 & 22 & 3 & 4.9 & 1.2 & 0.0 & 0.1 & 1.7 \\
\hline Lower Montane $^{4}$ & Affected by pollution & Ferral./Cambi. & 3810 & 82 & 3 & 10 & 39 & 5 & 7.2 & 1.9 & 0.1 & 0.3 & 3.0 \\
\hline Lower Montane ${ }^{5}$ & Affected by pollution & Ferral./Cambi. & 5289 & 135 & 7 & 18 & 80 & 7 & 21.4 & 1.7 & 0.0 & 0.3 & 33.0 \\
\hline Lower Montane ${ }^{5}$ & Mid successional & Ferral./Cambi. & 5682 & 128 & 3 & 14 & 56 & 13 & 3.7 & 3.5 & 0.1 & 0.3 & 10.1 \\
\hline Lower Montane ${ }^{5}$ & Mid successional & Ferral./Cambi. & 4460 & 98 & 2 & 11 & 30 & 9 & 2.4 & 2.4 & 0.1 & 0.2 & 5.9 \\
\hline AMAZONIAN D & ISE RAIN FORESTS & & & & & & & & & & & & \\
\hline Terra firme $^{6}$ & 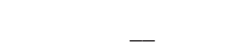 & - & 7400 & 106 & 2 & 13 & 18 & 13 & 1.2 & 0.7 & 0.0 & 0.1 & - \\
\hline Terra firme ${ }^{7}$ & Forest & Ferralsols & 6657 & 126 & 3 & 26 & 49 & 14 & 1.4 & 4.2 & 0.1 & 0.1 & - \\
\hline MIXED RAIN $F$ & ESTS (ARAUCARIA M & T FORESTS) & & & & & & & & & & & \\
\hline Alluvial $^{8}$ & Late successional & Fluvisols & 9400 & 199 & 18 & 42 & 132 & 21 & - & - & - & - & - \\
\hline Montane $^{9}$ & - & Acri. and Ferral. & 6527 & 89 & 6 & 32 & 63 & 16 & - & - & - & - & - \\
\hline SEMIDECIDUOI & FORESTS/SAVANNA & & & & & & & & & & & & \\
\hline Coastal $^{10}$ & Late successional & Acri. and Ferral. & 8340 & - & 3 & 23 & 49 & 14 & 1.3 & 0.4 & 0.4 & 0.4 & - \\
\hline Upper Montane $^{11}$ & - & - & 6700 & 128 & 3 & 26 & 66 & 13 & 1.9 & 3.7 & 0.5 & 0.5 & 10.1 \\
\hline Montane $^{12}$ & - & Ferralsols & 8643 & 198 & 7 & 48 & 149 & 27 & 4.9 & 2.8 & 0.3 & 0.3 & 9.2 \\
\hline Montane $^{11}$ & - & Ferralsols & 8600 & 174 & 5 & 40 & 146 & 20 & 1.7 & 3.7 & 0.3 & 0.3 & 4.0 \\
\hline Montane $^{13}$ & - & - & 8800 & 203 & 6 & 44 & 109 & 24 & 2.9 & 8.7 & 0.2 & 0.2 & 9.3 \\
\hline Montane $e^{14^{*}}$ & - & - & - & 184 & 5 & 39 & 148 & 20 & 3.7 & 8.7 & 0.2 & 0.2 & 9.3 \\
\hline Montane $^{15}$ & - & - & 11600 & 230 & 7 & 82 & 210 & 30 & 8.8 & 1.4 & 0.6 & 0.6 & - \\
\hline Montane $^{16}$ & Late successional & - & 9014 & 161 & 9 & 69 & 217 & 36 & 4.9 & 2.5 & 0.4 & 0.4 & 4.8 \\
\hline Montane $^{17}$ & Late successional & - & 12970 & 219 & 6 & 67 & 108 & 38 & 10.6 & 7.7 & 0.8 & 0.8 & 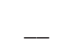 \\
\hline Montane $^{17}$ & Mid successional & - & 10460 & 166 & 5 & 50 & 89 & 29 & 10.0 & 6.7 & 0.7 & 0.7 & - \\
\hline Montane $^{18}$ & - & Ferralsols & 7770 & 118 & 4 & 35 & 32 & 24 & 18.3 & 5.3 & 0.2 & 0.2 & - \\
\hline Tall Savanna ${ }^{19}$ & - & Ferralsols & 7800 & 64 & 5 & 12 & 27 & 11 & - & - & - & - & - \\
\hline Savanna ${ }^{19}$ & - & Ferralsols & 2100 & 18 & 1 & 3 & 7 & 3 & - & - & - & - & - \\
\hline Savanna/Riparian & - & - & - & 107 & 5 & 29 & 52 & 17 & 3.6 & 2.5 & 0.2 & 0.2 & 20.1 \\
\hline
\end{tabular}

References: ${ }^{1}$ Moraes et al. (1999); ${ }^{2}$ Britez (1994); ${ }^{3}$ Pires (2001); ${ }^{4}$ Domingos et al. (2000); ${ }^{5}$ Leitão-Filho et al. (1993); ${ }^{6}$ Klinge \& Rodrigues (1968); ${ }^{7}$ Scott et al. $(1992) ;{ }^{8}$ Sousa (2003); ${ }^{9}$ Britez et al. (1992); ${ }^{10}$ Sampaio et al. (1988); ${ }^{11}$ Morellato (1992)/1987*; ${ }^{12}$ Pagano (1989); ${ }^{13}$ Cesar (1993); ${ }^{14}$ Schlittler (1990)*; ${ }^{15}$ Diniz (1987); ${ }^{16}$ Santos (1989); ${ }^{17}$ Toledo et al. (2002); ${ }^{18}$ Dias \& Oliveira-Filho (1997); ${ }^{19}$ Peres et al. (1983); ${ }^{20}$ Delitti (1984)*. * Listed by Britez (1994). 
more eutrophic soils, alluvial Araucaria moist forests, and Atlantic rain forests affected by pollutants. Forests over sandy soils, such as "restingas", "cerrados" (savannas), and the transition formations between "Caatinga" and Amazon biomes, had a lower range ( 5 to $8 \mathrm{~g}$ / $\mathrm{kg}$ ), even though some species can present very high concentrations in leaf litter (Pinto \& Marques 2003).

The fundamental metabolic processes involving carbohydrates in flowering, fruiting and seed formation have a relevant contribution for the significantly higher levels of $\mathrm{P}$ and $\mathrm{K}$ in the fraction comprising the reproductive parts (Mengel \& Kirkby 1982). The lowest concentrations of $\mathrm{P}$ among the studied fractions were observed in the twig fraction. Among the studied species, significantly lower P concentrations were observed in T. pulchra, $C$. pachystachya and M. coriacea. P concentrations were similar to other Atlantic rain forests and in Araucaria moist forests $(0.6$ to $1 \mathrm{~g} / \mathrm{kg})$. Forests growing on more eutrophic soils have demonstrated higher levels of $\mathrm{P}$ in litterfall, generally above $1 \mathrm{~g} / \mathrm{kg}$. Values ranging from 0.2 and $0.5 \mathrm{~g} / \mathrm{kg}$ were reported for "restinga" and Amazonian "Terra Firme" forests, indicating that $\mathrm{P}$ is a limiting element in these tropical ecosystems (Vitousek 1984). The low P concentrations found in this study indicate high $\mathrm{P}$ use efficiency. The K concentrations (about $4 \mathrm{~g}$ / $\mathrm{kg}$ ) were slightly higher than in other Atlantic rain forests (Pinto \& Marques 2003) and lower than most of the other forests (Britez et al. 1992, Dias \& Oliveira-Filho 1997).

The highest $\mathrm{Ca}$ and $\mathrm{Mg}$ concentrations were observed in leaf litter. Concentrations of Ca in leaf litter of T. pulchra were significantly higher than in leaf litter of other species. $C$. myrianthum leaf litter had the highest $\mathrm{Mg}$ concentrations. Ca concentrations were intermediate compared to other Atlantic rain forests and to Araucaria forests (Britez et al. 1992, Sousa 2003) where values range between 9 and $17 \mathrm{~g} / \mathrm{kg}$ of dry weight (Leitão-Filho et al. 1993, Pinto \& Marques 2003). Brazilian semideciduous forests contained higher Ca concentrations, (13 to $40 \mathrm{~g} / \mathrm{kg}$ ). In oligotrophic soils, the reported values were between 3 and $9 \mathrm{~g} /$ $\mathrm{kg}$, suggesting high Ca use efficiency. Similar values have been reported in deciduous forests in Southeastern Brazil (Pagano 1989, Santos 1989). The Mg concentrations obtained in the present study (about $2.5 \mathrm{~g} / \mathrm{kg}$ ) were similar to those reported in other studies (Britez et al. 1992, Britez 1994).

Micronutrient and aluminum concentrations in components of litterfall: Higher $\mathrm{Fe}$ concentrations in leaves than in twigs and reproductive parts can be explained by its lower Fe mobility between different plant organs and its presence in the chlorophyll structure as $\mathrm{Mg}$ (Mengel \& Kirkby 1982). Concentrations of Mn in T. pulchra leaf litter were significantly lower than in other species. The lowest levels of $\mathrm{Cu}$ were found in C.pachystachya, while the lowest levels of $\mathrm{Zn}$ were observed for both $T$. pulchra and $C$. pachystachya. Concentrations of $\mathrm{Mn}$ in the leaf litter of other species (all leaves except that of selected species) and $A$. glandulosa were significantly higher than that observed for other species studied. The highest $\mathrm{Cu}$ concentrations were observed in P. guajava and $C$. myrianthum leaf litter. Micronutrients are not often quantified in litterfall studies (Moraes et al. 1999) and the few data available (e.g. Fe and $\mathrm{Mn}$ ) are quite variable. However, the resulting gradient in micronutrient concentration observed here $(\mathrm{Mn}>\mathrm{Fe}>\mathrm{Zn}>\mathrm{Cu})$ was also observed in podzols of Atlantic rain forests (Britez 1994, Moraes et al. 1999) and in Amazonian forests (Klinge \& Rodrigues 1968).

Aluminum concentrations (2 $500 \mathrm{mg} / \mathrm{kg}$ in average) were higher in the studied sites compared to other forests due to the presence of T. pulchra, and were lower than Atlantic rain forests affected by air pollution (LeitãoFilho et al. 1993) where this species can also be found. T. pulchra has about 35 times more Al than other species $(14000 \mathrm{mg} / \mathrm{kg}$ of dry matter). These plants have a high capacity for $\mathrm{Al}$ uptake and accumulation and are very well adapted to high Al availability in acid soils, which are common in Atlantic rain forests (Domingos et al. 2003). A possible mechanism 
for detoxification of $\mathrm{Al}$ consists of: Al uptake through Al-F (fluoride) or Al-citrate complexes and storage in large intercellular spaces in the leaf apoplast, together with $\mathrm{Si}$ (silicon) or Aloxalate complexes (Mengel \& Kirkby 1982, Klumpp et al. 1996, Britez 2001, Jansen et al. 2002, Domingos et al. 2003). Other species in this forest community may have mechanisms that facilitate $\mathrm{Al}$ exclusion. Membrane impermeability of toxic forms, exudation of chelant organic acids and carboxylate complexes in rizosphere can prevent Al-toxicity in aerial plant parts (Mengel \& Kirkby 1982, Klumpp et al. 1996, Jansen et al. 2002). Al availability may stimulate the growth of some species of Tibouchina (Jansen et al. 2002). As already mentioned, $T$. pulchra also contained high levels of $\mathrm{Ca}$ in leaf litter. The $\mathrm{Ca}-\mathrm{H}$ or $\mathrm{Ca}-\mathrm{Al}$ exchange reactions in the upper soil layers provide an efficient buffer for soil acidity (Ranger et al. 2003). T. pulchra was a very common pioneer species, mainly in site 2 (about $20 \%$ of basal area, $1.4 \mathrm{~m}^{2} / \mathrm{ha}$ ). Further investigations are needed to characterize the precise role of T.pulchra in the Al cycle during succession and its influence in other species of the forest community.

Litterfall mineral element fluxes: The quantity of nutrients and organic matter returned to the forest floor are very important factors in successional stages of vegetation for the restoration of soil organic resulting in higher availability of nutrients in this compartment. The sum of macronutrient fluxes in litterfall reached $217 \mathrm{~kg} / \mathrm{ha} / \mathrm{yr}$ in site 1 and $104 \mathrm{~kg} / \mathrm{ha} / \mathrm{yr}$ in site 2 . Values ranging from 150 to $280 \mathrm{~kg} / \mathrm{ha} / \mathrm{yr}$ were measured in many Amazonian and Atlantic rain forests and Araucaria moist forests. Semideciduous forests showed the highest values, ranging from 215 to $645 \mathrm{~kg} / \mathrm{ha} / \mathrm{yr}$. Macronutrient fluxes ranging from 75 to $180 \mathrm{~kg} / \mathrm{ha} / \mathrm{yr}$ were reported for forests over sandy (oligotrophic) soils, "cerrados", lowland and "restinga" forests. Therefore, even though the studied area is a regenerating forest (nine to ten years old), it produces substantial amounts of nutrients in litterfall, what indicates high productivity.
Oligodominance, which is very common in the earlier stages of secondary succession, can explain the major contributions of $C$. pachystachya and T. pulchra in total litterfall from site 2, where the least advanced vegetation dominated (site 2) as well as its lower proportion of twigs in litterfall. $M$. coriacea leaf litter was responsible for the highest annual amount of $\mathrm{N}$ and $\mathrm{K}$ deposition in site 1, while $C$. myrianthum was responsible for the greatest annual amount of $\mathrm{P}, \mathrm{Ca}$ and $\mathrm{Mg}$. $C$. pachystachya and $T$. pulchra showed the highest annual contribution of all analyzed macro and micronutrients in site 2 due to their higher leaf litter mass.

M. coriacea leaf litter contributed to the highest annual input of $\mathrm{Fe}$ to the forest soil, while A. glandulosa contributed to the highest annual input of $\mathrm{Mn}$, and $C$. myrianthum to the highest annual additions of $\mathrm{Cu}$ and $\mathrm{Zn}$ in site 1 .

T. pulchra contributed with up to $24 \%$ of leaf fall and $82 \%$ of $\mathrm{Al}$ returned to soil through litterfall in site 2. The $\mathrm{Al}$ flux at this site was similar to that of site 1 . In a "restinga" forest near the study area, Britez (2001) noticed that Faramea marginata (Rubiaceae), an Alaccumulating species, contributed approximately with $60 \%$ of the total $\mathrm{Al}$ input thoughtotal litterfall, although it contributed with only $2 \%$ of total leaf litter. Determining how $\mathrm{Al}$ is deposited on the soil surface will help to understand whether it will be available to plants in litter standing crops or not.

The role of potential species in soil restoration along succession: The lowest $\mathrm{N}, \mathrm{P}$, $\mathrm{Mn}, \mathrm{Zn}$ and $\mathrm{Cu}$ concentrations were observed in leaf litter of M. coriacea, T. pulchra and C. pachystachya. These species had greatest importance in arboreal community structure (Gatti et al. unpublished data), litter production, carbon and nutrient transfer in both sites, showing relative high efficiency in the use of those nutrients. In similar areas in Southern and Southeastern Brazil, C. pachystachya is generally the first arboreal species to colonize the land after grazing or agriculture have stopped. The lowest $\mathrm{N}$ concentrations in leaf litter indicated 
that $C$. pachystachya seems to tolerate better $\mathrm{N}$ degraded soils, emphasizing its importance in the early stages of secondary succession. As previously stated, this species was responsible for $24 \%$ of $\mathrm{N}$ returned to the soil through litterfall in site $2(10.3 \mathrm{~kg} / \mathrm{ha} / \mathrm{yr})$, and for only $5 \%$ of the $\mathrm{N}$ input in site 1 (most advanced vegetation) $(4.8 \mathrm{~kg} / \mathrm{ha} / \mathrm{yr})$. A similar pattern for P seems to occur with $C$. pachystachya and $T$. pulchra. M. coriacea and S. multijuga had the highest $\mathrm{Ca}$ use efficiency or presented a lower demand for this nutrient in their leaves. In other words, they produced considerable amounts of litter with low levels of Ca. T. pulchra has a high capacity of $\mathrm{Al}$ uptake and accumulation and is very well adapted to high Al availability in common acid soils, mainly in degraded sites of the Atlantic rain forest.

Finally, during secondary succession, each group of species seems to perform a different role in restoring the original characteristics of the soil surface horizons, such as increasing organic matter and nutrient availability and alleviation of toxicity for plants. Such features should be considered in forest restoration programs.

\section{ACKNOWLEDGMENTS}

We would like to thank many professors from the Federal University of Paraná (UFPR) for their helpful comments and suggestions. We are grateful to many colleagues of the "Succession Project" (Alan Mocochinski, André Cavassani, Francisco Putini e Alexandre Lorenzetto). This research was supported by the "Fundação Grupo Boticário de Proteção à Natureza". We also thank the Brazilian Research Council (CNPq) and the Brazilian Funding Agency (CAPES) for the scholarship granted to Scheer, M.B. We are greatly indebted to the Fritz Müller Society of Natural Sciences (Mülleriana) and to the Forestry Pos Graduation Program of UFPR. We also thank Peter Vitousek, Kelly Gutseit and Roman Carlos Rios for helpful comments.

\section{RESUMEN}

Durante la sucesión secundaria forestal, el flujo de nutrientes en la hojarasca se incrementa significativamente. Los altos ingresos de materia orgánica y nutrientes a través de la hojarasca afecta positivamente la fertilidad del suelo y la composición de especies, las cuales son componentes esenciales para programas de restauración forestal y de manejo. En el presente estudio, el ingreso de nutrientes a través de la hojarasca y sus componentes fueron estimados para dos sitios de una selva lluviosa atlántica aluvial en sucesión temprana. La cantidad anual de elementos que ingresan al suelo desde la vegetación más desarrollada (sitios con alta área basal y abundancia de árboles) fueron (en kg/ha): $93 \mathrm{~N}, 79 \mathrm{Ca}, 24 \mathrm{~K}, 15 \mathrm{Mg}, 6 \mathrm{P}, 1.7 \mathrm{Mn}, 0.94$ $\mathrm{Fe}, 0.18 \mathrm{Zn}, 0.09 \mathrm{Cu}$ y $11.2 \mathrm{Al}$. Menos de la mitad de esas cantidades fueron aportadas por la vegetación menos desarrollada, excepto para el Al. La cantidad de Al aportada a este sitio fue similar a la contribución de la vegetación más desarrollada, debido a la contribución de: Tibouchina pulchra ( $82 \%$ de todo el $\mathrm{Al}$ aportado). La eficiencia en el uso de nutrientes de la hojarasca (principalmente de $\mathrm{N}$ y $\mathrm{P}$ ) de la vegetación menos desarrollada fue superior a la eficiencia de una más desarrollada, debido a la alta proporción de tres especies nativas dominantes (Myrsine coriacea, Tibouchina pulchra y Cecropia pachystachya) en la primera. Si bien la hojarasca de esas especies presenta menor concentración de nutrientes que las otras especies arbóreas, el flujo de nutrientes fue mayor (para ambos sitios), marcando una cierta independencia de los nutrientes esenciales del suelo. Las cantidades de esas especies deberían ser consideradas con mayor atención para su uso en programas de restauración forestal.

Palabras clave: producción de hojarasca, ciclo de nutrientes, eficiencia en el uso de nutrientes, sucesión secundaria, selva lluviosa tropical.

\section{REFERENCES}

Binkley, D., J.L. Stape \& M.G. Ryan. 2004. Thinking about efficiency of resource use in forests. Forest Ecol. Manag. 193: 5-16.

Bray, J.R. \& E. Gorham. 1964. Litter production in forests of the world. Adv. Ecol. Res. 2: 101-157.

Britez, R.M., C.B. Reissmann, S.M. Silva \& A. SantosFilho. 1992. Deposição estacional de serapilheira e macronutrientes em uma floresta de Araucária, São Mateus do Sul, Paraná. In Congresso Nacional de Essências Nativas, 2. Revista do Instituto Florestal 4: 766-772.

Britez, R.M. 1994. Ciclagem de nutrientes minerais em duas florestas da planície litorânea da Ilha do Mel, 
Paranaguá, PR. Master Thesis, Universidade Federal do Paraná, Curitiba, Paraná, Brazil.

Britez, R.M. 2001. Efeito do alumínio em duas espécies arbóreas da planície litorânea da Ilha do Mel, PR. Ph.D. Thesis, Universidade Federal do Paraná, Curitiba, Paraná, Brazil.

Brown, S. \& A. Lugo. 1982. The storage and production of organic matter in tropical forest and their role in the global carbon cycle. Biotropica 14: 161-187.

Cesar, O. 1993. Nutrientes minerais da serapilheira produzida na mata mesófila semidecídua na fazenda Barreiro Rico, município de Anhembi, SP. Rev. Bras. Biol. 53: 659-669.

Dias, H.C.T. \& A.T. Oliveira-Filho. 1997. Variação temporal e espacial da produção de serapilheira em uma floresta estacional semidecídua Montana em Lavras, MG. Rev. Árvore 21: 11-26.

Dent, D.H., R. Bagchi, D. Robinson, N. Majalap-Lee \& D.F.R.P. Burslem. 2006. Nutrient fluxes via litterfall and leaf litter decomposition vary across a gradient of soil nutrient supply in a lowland tropical rain forest. Plant Soil 288: 197-215.

Diniz, S. 1987. Ciclagem de nutrientes associados aos processos de produção e decomposição do folhedo em um ecossistema de mata mesófila semi-decídua, no município de Araras, SP. Master Thesis, Universidade Estadual Paulista, São Paulo, Brazil.

Domingos, M., F. Poggiani, Y. Struffaldi De Vuono \& M.I.M.S. Lopes. 1990. Produção de serapilheira na floresta da Reserva Biológica de Paranapiacaba, sujeita aos poluentes atmosféricos de Cubatão, SP. Hoehnea 17: 47-58.

Domingos, M., R.M. Moraes, Y. Struffaldi De Vuono \& C.E. Anselmo. 1997. Produção de serapilheira e retorno de nutrientes em um trecho de Mata Atlântica secundária, na Reserva Biológica de Paranapiacaba, SP. Rev. Bras. Bot. 20: 91-96.

Domingos, M.L., M.I.M. Silveira \& Y. Struffaldi De Vuono. 2000. Nutrient cycling disturbance in Atlantic Forest sites affected by air pollution coming from the industrial complex of Cubatão, Southeast Brazil. Rev. Bras. Bot. 23: 77-85.

Domingos, M., A. Klumpp, M.C.S. Rinaldi, G. Klumpp, I.F. Modesto \& W.B.C. Delitti. 2003. Combined effects of air and soil pollution by fluoride emissions on Tibouchina pulchra Cogn., at Cubatão, SE Brazil, and their relations with aluminum. Plant Soil 249: 297-308.
Gatti, G.A. 2000. Composição florística, fenologia e estrutura da vegetação de uma área em restauração ambiental, Guaraqueçaba, PR. Master Thesis, Universidade Federal do Paraná, Curitiba, Paraná, Brazil.

Gallardo, J.F., A. Martín \& G. Moreno. 1999. Nutrient efficiency and resorption in Quercus pyrenaica oak coppices under different rainfall regimes of the Sierra de Gata mountains (central western Spain). Ann. For. Sci. 56: 321-331.

Jansen, S., M. Broadley, E. Robbrecht \& E. Smets. 2002. Aluminum hyperaccumulation in angiosperms: a review of its phylogenetic significance. Bot. Rev. 68: 235-269.

Killingbeck, K.T. 1996. Nutrients in senesced leaves: keys to the search for potential resorption and resorption efficiency. Ecology 77: 1716-1727.

Klinge, H. \& W.A. Rodrigues. 1968. Litter production in an area of Amazonian terra firme forest. Part II. Mineral content of the litter. Amazoniana 1: 303-310.

Klumpp, A., G. Klumpp, M. Domingos \& M.D. Silva. 1996. Fluoride impact on native tree species of the atlantic forest near Cubatão, Brazil. Water Air Soil Poll. 87: 57-71.

Leitão-Filho, H.F., S.N. Pagano, O. Cesar, J.L. Timoni \& J.J. Rueda. 1993. Ecologia da Mata Atlântica em Cubatão. Editora da UNESP, São Paulo, Brazil.

Lugo, A.E., L.W. Silver \& S.M. Colón. 2004. Biomass and nutrient dynamics of restored neotropical forests. Water Air Soil Poll. 4: 731-746

Maack, R. 1968. Geografia física do estado do Paraná. UFPR, Curitiba, Paraná, Brazil.

Martins, A.P.L. \& C.B. Reissmann. 2007. Material vegetal e as rotinas laboratoriais nos procedimentos químico-analíticos. Sci. Agr. 8: 1-17.

Mengel, K. \& E.A. Kirkby. 1982. Principles of plant nutrition. International Potash Institute, Switzerland.

Moraes, R.M., W.B.C. Delitti \& Y. Struffaldi De Vuono. 1999. Litterfall and litter nutrient content in two Brazilian tropical forests. Rev. Bras. Bot. 22: 9-16.

Morellato, L.P.C. 1992. Nutrient cycling in two South-East Brazilian forests. I Litterfall and litter standing crop. J. Trop. Ecol. 8: 205-215.

Pagano, S.N. 1989. Nutrientes minerais do folhedo em mata mesófila semidecídua no município de Rio Claro, SP. Rev. Bras. Biol. 49: 641-647. 
Peres, J.R.R., A.R. Suhet, M.A.T. Vargas \& A. Drozdowicz. 1983. Litter production in areas of Brazilian “cerrados". Pesqui. Agropecu. Bras. 18: 1037-1043.

Pinto, C.B. \& R. Marques. 2003. Aporte de nutrientes por frações da serapilheira em sucessão ecológica de um ecossistema da floresta Atlântica. Floresta 33: $257-264$

Pires, L.A. 2001. Aspectos da ciclagem de nutrientes em uma formação de restinga na Ilha do Mel. Master Thesis, Universidade Estadual Paulista Julio Mesquita Filho, Rio Claro, São Paulo, Brazil.

Prescott, C. 2005. Do rates of litter decomposition tell us anything we really need to know? For. Ecol. Manage. 220: $66-74$

Ranger, J., F. Gerard, M. Lindemann, D. Gelhaye \& L. Gelhaye. 2003. Dynamics of litterfall in a chronosequence of Douglas-fir (Pseudotsuga menziesii Franco) stands in Beaujolais mounts (France). Ann. For. Sci. 60: 475-488

Rodin, L.E. \& N.I. Basilevich. 1967. Production and mineral cycling in terrestrial vegetation. Oliver and Boyd, Edinburgh, Scotland, United Kingdom.

Sampaio, E.V.S.B., K.S. Nunes \& E. Lemos. 1988. Ciclagem de nutrientes na mata de Dois Irmãos (Recife - PE) através da queda de serapilheira. Pesqui. Agropecu. Bras. 23: 1055-1061.

Santos, V.D. 1989. Ciclagem de nutrientes minerais em mata tropical subcaducifolia nos planaltos do Paraná (Parque Estadual Vila Rica do Espírito Santo - Fênix/ PR). Ph.D. Thesis, Universidade de São Carlos, São Carlos, São Paulo, Brazil.

Scheer, M.B. 2008. Leaf litter decomposition and nutrient release on a secondary successional alluvial Atlantic Rain Forest in Southern Brazil (in Portuguese). Floresta 38: 253-266.

Scheer, M.B. 2009. Nutrient flow in rainfall and throughfall in two stretches in an Atlantic Rain Forest in Southern Brazil (in Portuguese). Floresta 39: 117-130.
Scheer, M.B., G. Gatti, C. Wisniewski, A.Y. Mocochinski, A.T. Cavassani, A. Lorenzetto \& F. Putini. 2009. Patterns of litter production in a secondary alluvial Atlantic Rain Forest in Southern Brazil. Rev. Bras. Bot. 32: 805-817.

Scott, D.A., J. Proctor \& J. Thompson. 1992. Ecological studies on a lowland evergreen rain forest on Maracá Island, Roraima, Brazil. II. Litter and nutrient cycling. J. Ecol. 4: 705-717.

Silver, W.L. 1994. Is nutrient availability related to plant nutrient use in humid tropical forests? Oecologia 98: 336-343.

Sousa, S.G.A. 2003. Produção e decomposição de serapilheira de uma floresta ombrófila mista aluvial, Rio Barigui, Araucária, PR. Ph.D. Thesis, Universidade Federal do Paraná, Curitiba, Paraná, Brazil.

Toledo, L.O., M.G. Pereira \& C.E.G. Menezes. 2002. Produção de serapilheira e transferência de nutrientes em florestas secundárias localizadas na região de Pinheiral, RJ. Ciência Florestal 12: 9-16.

Veloso, H.P., A.L. Rangel Filho \& J.C.A. Lima. 1991. Classificação da vegetação brasileira, adaptada a um sis tema universal. IBGE, Departamento de Recursos Naturais e Estudos Ambientais, Rio de Janeiro, Brazil.

Vitousek, P.M. 1982. Nutrient cycling and nutrient use efficiency. Am. Nat. 119: 553-572.

Vitousek, P.M. 1984. Litterfall, nutrient cycling, and nutrient limitation in tropical forests. Ecology 65: 285-298.

Vitousek, P.M. 1997. On regression and residuals: response to Knops et al. Oecologia 110: 557-559.

Vitousek, P.M. \& W.A. Reiners. 1975. Ecosystem succession and retention: a hypothesis. BioScience 25 : 376-381. 